\title{
Blinded and stimulator guided comparison of suprascapular nerve block in hemiplegic shoulder pain: a pilot study
}

\author{
Hemiplejik omuz ağrısında kör ve stimülatör kllavuzluğunda supraskapular \\ sinir blokajinın karşılaştırılması: Pilot çalışma \\ Duygu Geler Külcü, ${ }^{1}$ Aslıhan Taraktaș, ${ }^{2}$ Naciye Badur, ${ }^{2}$ Pelin Çizmeci, ${ }^{3}$ Feyza Ünlü Özkan, ${ }^{2}$ İlknur Aktaş \\ ${ }^{1}$ Department of Physical Medicine and Rehabilitation, Haydarpaşa Numune Training and Research Hospital, İstanbul, Turkey \\ ${ }^{2}$ Department of Physical Medicine and Rehabilitation, Fatih Sultan Mehmet Training and Research Hospital, İstanbul, Turkey \\ ${ }^{3}$ Department of Algology, Fatih Sultan Mehmet Training and Research Hospital, İstanbul, Turkey
}

Received / Geliș tarihi: October 2015 Accepted / Kabul tarihi: March 2016

\begin{abstract}
Objectives: This study aims to compare the superiority of different suprascapular nerve block (SSNB) application methods on hemiplegic shoulder pain (HSP), in a blinded and stimulator guided manner.

Patients and methods: Twenty-six stroke patients (19 males, 7 females; mean age 61.0 \pm 9.4 years; range 53 to 76 years) meeting the enrollment criteria, were included in this study between September 2014 and November 2014. Patients were randomly divided into two equal groups. Patients in group A received blinded SSNB and patients in group B received stimulator guided SSNB. Range of motion (ROM) (by goniometer) and pain levels (by visual analog scale-VAS) were assessed. Evaluations were made before, one hour after and one week after SSNBs.

Results: In each group, VAS pain scores significantly decreased over time $(\mathrm{p}<0.0001)$ and a significant increase in terms of flexion and abduction ROM angles (group A: $p=0.002$ and $p=0.010$; group $B$ : $p=0.004$ and $p=0.012$, respectively) was observed. In addition, internal rotation ROM angles were found to have increased in group B ( $\mathrm{p}=0.036)$. There were no significant differences in ROM and VAS one hour and one-week change scores between the two groups ( $\mathrm{p}>0.05)$.

Conclusion: Both blinded or stimulator guided suprascapular nerve block techniques were safe and effective for pain relief in hemiplegic shoulder pain management. None of the injection techniques was superior to the other.
\end{abstract}

Keywords: Blinded; hemiplegic shoulder pain; stimulator guided; suprascapular nerve block.

$\ddot{O} Z$

Amaç: Bu çalışmada hemiplejik omuz ağrısında (HOA) kör ve stimülatör kılavuzluğunda, farklı supraskapular sinir blokajı (SSSB) uygulama yöntemlerinin birbirlerine üstünlüğü araştırıldı.

Hastalar ve yöntemler: Eylül 2014 - Kasım 2014 tarihleri arasında yapılan bu çalışmaya katılma kriterlerini karşılayan 26 inme hastası (19 erkek, 7 kadın; ort. yaş 61.0 9.4 yıl; dağılım 53-76 yıl) dahil edildi. Hastalar randomize olarak iki eşit gruba ayrıldı. Grup A'daki hastalara kör SSSB, grup B'deki hastalara ise stimülatör kılavuzluğunda SSSB verildi. Eklem hareket açıklığı (EHA) (gonyometre ile) ve ağrı düzeyleri (görsel analog ölçeği-GAÖ ile) değerlendirildi. Ölçümler SSSB öncesinde, bir saat sonrasında ve bir hafta sonrasında yapıldı.

Bulgular: Her iki grupta GAÖ ağrı skorlarında zamanla anlamlı olarak azalma ( $\mathrm{p}<0.0001)$; fleksiyon ve abdüksiyon EHA açılarında (sırasıyla grup A: $\mathrm{p}=0.002$ ve $\mathrm{p}=0.010$; grup $\mathrm{B}: \mathrm{p}=0.004$ ve $\mathrm{p}=0.012$ ) ise anlamlı artış gözlendi. Ek olarak grup $\mathrm{B}$ internal rotasyon EHA açılarında artış saptandı ( $\mathrm{p}=0.036)$. Gruplar arasında, GAÖ ve EHA açıları bir saatlik ve bir haftalık değişim skorlarında anlamlı bir farklılık yoktu ( $\mathrm{p}>0.05)$. Sonuç: Kör ya da stimülatör kılavuzluğunda yapılan supraskapular sinir blokajı tekniklerinin her ikisi de güvenli ve hemiplejik omuz ağrısı tedavisinde ağrının giderilmesinde etkilidir. Hiçbir enjeksiyon tekniği diğerinden üstün değildir.

Anabtar sözcükler: Kör; hemiplejik omuz ağrısı; stimülatör k1lavuzlu; supraskapular sinir blokajı.

Corresponding author / İletişim adresi: Duygu Geler Külcü, MD. Haydarpaşa Numune Eğitim ve Araştırma Hastanesi, Fiziksel Tıp ve Rehabilitasyon Kliniği, 34668 Üsküdar, İstanbul, Turkey. e-mail / e-posta: d_geler@yahoo.com 
Stroke constitutes a significant portion of hospitalizations due to neurological diseases. Various medical problems and complications may occur after stroke. It has been reported that shoulder pain (24\%) is the most prevalent complication after depression (26\%) in hemiplegic patients. ${ }^{[1,2]}$ Hemiplegic shoulder pain (HSP) is correlated with prolonged hospitalization, difficulty in the rehabilitation process and impairment in functional use of the arm. ${ }^{[3]}$ If the patient's pain is reduced, an optimal exercise program may be applied to improve range of motion (ROM) angles. ${ }^{[4]}$ In order to relieve pain; various treatment modalities such as physical therapies, functional electrical stimulation, oral or intra-articular steroid injections, stellate ganglion block and peripheral nerve blocks have been used. ${ }^{[5]}$

Recently, suprascapular nerve block (SSNB) has been commonly preferred for the treatment of shoulder disorders. The suprascapular nerve supplies $70 \%$ of sensorial fibers to the shoulder. Pain reduction is achieved by blocking these sympathetic pain fibers. SSNB has been found to be a safe and effective treatment for shoulder pain associated with rheumatoid arthritis, rotator cuff lesions, adhesive capsulitis and degenerative shoulder conditions. ${ }^{[6]}$

Although the blinded method of SSNB by the help of anatomical and bony landmarks has been found to be effective and safe, it can be difficult to reach the suprascapular notch in hemiplegic patients because of anatomical changes. ${ }^{[7,8]}$

In this study, we aimed to investigate the efficacy of blinded SSNB in HSP by comparing it with stimulator guided SSNB.

\section{PATIENTS AND METHODS}

This study was an assessor blinded randomized prospective trial. It was approved by the Fatih Sultan Mehmet Training and Research Hospital Local Ethics Committee and all subjects provided written informed consent prior to data collection. The study was conducted in accordance with the principles of the Declaration of Helsinki.

The trial included 26 patients with hemiplegia, 19 males and 7 females, with a mean age of $61.0 \pm 9.4$ years and an average time since stroke of $21.7 \pm 20.5$ months, were admitted into this study who were referred from all over the country for late outpatient rehabilitation between September 2014 and November 2014. Stroke is defined as focal or global acute neurological event due to cerebrovascular origin lasting for at least 24 hours; diagnosed by a neurologist and confirmed by computed tomography (CT) or magnetic resonance imaging (MRI). Inclusion criteria were as follows: (i) first episode of unilateral cerebrovascular accident with hemiplegia, (ii) ability to understand and follow commands, (iii) shoulder pain with visual analog scale (VAS) pain score $>3$, and (iv) consent to participate in the study. The patients who suffered from neglect, neuropathic pain, pressure sores, any infection (urinary, respiratory, etc.), hypersensitivity to injection agents, previous SSNB or any shoulder injection were excluded. None of the subjects regularly took pain medication.

The physician who performed the VAS pain evaluation and shoulder ROMs was blinded to the groups. Patients were randomly assigned to one of the two groups after their preliminary evaluation. The subjects were allocated using a coin-tossing method by an investigator who was blinded about the measurements. After randomization, 13 patients were assigned to the blinded SSNB group (group A), and the remaining 13 were assigned to the stimulator guided SSNB group (group B). There were no losses in either group.

Demographic information (age, gender), medical history (including the time since stroke, side of involvement and lesion type) were recorded and information on accompanying medication use were obtained. A full physical examination including neurological and musculoskeletal evaluation was performed. Brunnstrom stage of upper extremity and presence of spasticity (by modified Ashworth scale) were recorded.

Group A: This group received a blinded suprascapular nerve block injection to the affected shoulder. In this technique, application is made to the posterior side of the shoulder. Suprascapular nerve block was performed using superficial anatomic landmarks while the patient was in a sitting position. Spine of the scapula was marked by horizontal line and a vertical line drawn in cephalad direction in order to divide scapula into two equal parts. ${ }^{[9]}$

The needle was placed $2 \mathrm{~cm}$ lateral and $1.5 \mathrm{~cm}$ above the intersection of horizontal and vertical lines (Figure 1a). Ten milliliter of injection solution ( $9 \mathrm{~mL}$ of prilocaine $1 \%$ and $1 \mathrm{~mL}$ of betamethasone) was delivered into the suprascapular notch. All injections were performed in a sterile environment. The same solution was used for nerve blockage in both groups. 

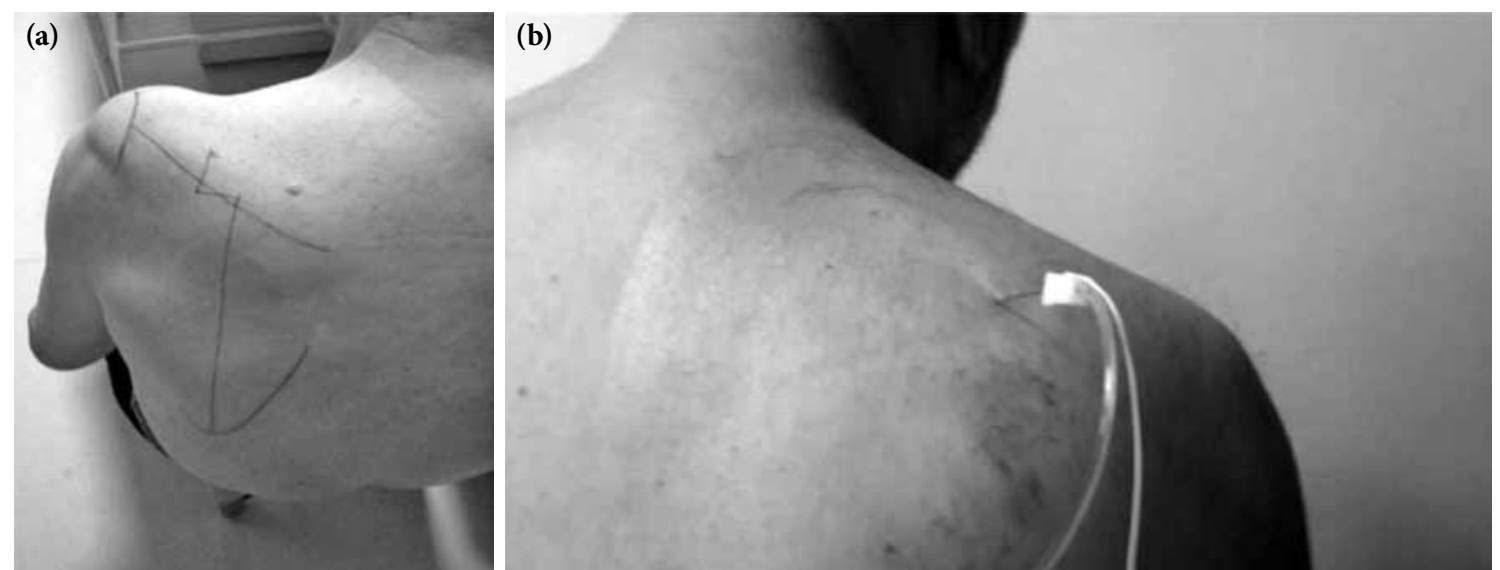

Figure 1. (a) Surface anatomy landmarks for blinded suprascapular nerve block application. (b) Stimulator guided suprascapular nerve block application.

Group B: Suprascapular nerve block was performed using the posterior approach described by Moore while the patients were sitting and leaning forward. Scapula was divided with a line drawn through the spine scapula. Later this line was divided into two by a vertical line and four quadrants were formed. From bisection point to the outer quadrant, a line was drawn with 45 degree angle and $2.5 \mathrm{~cm}$ distance and marked. Twenty-two Gauge (G), $50 \mathrm{~mm}$ needle was injected perpendicular to the skin from that marked point. Suprascapular nerve was found using a stimulator (Stimuplex HNS 11; B. Braun Melsungen AG, Melsungen, Germany). Two milliamperes $0.5 \mathrm{~V}$ current which caused contractions of supraspinatus and infraspinatus muscles leading abduction and external rotation of the arm (Figure $1 \mathrm{~b}$ ).

Pain intensity was recorded with VAS to measure the level of pain on a scale of $0-10 \mathrm{~cm}$. All ROM measurements were taken in the supine position and the shoulder was stabilized to prevent hitching. Shoulder flexion, abduction, internal and external rotation were measured with goniometer. Shoulder flexion and abduction were measured in neutral rotation with the elbow extended. Shoulder internal rotation, and external rotation were measured at 90 degrees of abduction of the arm with the elbow flexed to 90 degrees and the forearm in mid-position. Evaluations were made before the injection, one-hour and one week after the injection. In both groups, we have not identified any related to the injection such as transient vagal symptoms, pneumothorax, nerve injury and local tenderness at the injection site.

\section{Statistical analysis}

IBM SPSS Statistics version 22.0 program (IBM Corp., Armonk, NY, USA) and R 3.2.3 program were used for statistical analysis. Compliance with the normal distribution of parameters was evaluated by the Shapiro Wilks test. Qualitative data is compared by Continuity (Yates) Correction and Fisher's exact test.

Comparison of quantitative data between two groups was analyzed with Student's t test for normally distributed parameters and Mann-Whitney U test for abnormally distributed parameters. Variables were presented as median (minimum-maximum) or mean \pm standard deviation where appropriate.

Interaction effects were analyzed by two way mixed ANOVA for normally distributed parameters and F1_LD_F1 design for abnormally distributed parameters. Friedman test was performed in order to compare initial, first hour and first week repetitive measurements of abnormally distributed parameters, Wilcoxon sign rank test with Bonferroni correction was used for identifying time which caused inconsistency. A $p$ value was set as $<0.02$. Repeated measures of ANOVA was performed in order to compare initial, first hour and first week repetitive measurements of normally distributed parameters, Fisher's Least Significant Difference (LSD) test was used for identifying time which caused inconsistency. A $p$ value was set as $<0.05$.

\section{RESULTS}

The trial included patients whose mean stroke time was $21.7 \pm 20.5$ months. The etiology was ischemic in 20 patients and hemorrhagic in six patients. The left side was affected in 16 patients; all the patients were right handed. There were no significant differences between groups in terms of demographic properties. 
Table 1. Comparisons of demographic properties of the groups/biographical characteristics

\begin{tabular}{|c|c|c|c|c|c|c|c|c|c|c|c|c|}
\hline & \multicolumn{5}{|c|}{ Group A } & \multicolumn{5}{|c|}{ Group B } & \multirow[b]{2}{*}{ Test value } & \multirow[b]{2}{*}{$p$} \\
\hline & $\mathrm{n}$ & $\%$ & Mean \pm SD & Median & Min.-Max. & $\mathrm{n}$ & $\%$ & Mean \pm SD & Median & Min.-Max. & & \\
\hline Age (years) & & & $63.3 \pm 7.8$ & & $53-76$ & & & $58.7 \pm 11.0$ & & $28-72$ & 1,231 & $0.418^{\star}$ \\
\hline Gender & & & & & & & & & & & & $1.000 \dagger$ \\
\hline Male & 10 & 77 & & & & 9 & 69 & & & & & \\
\hline Female & 3 & 23 & & & & 4 & 31 & & & & & \\
\hline Time since stroke (months) & & & & 8 & $4-60$ & & & & 18 & $4-72$ & 50.500 & $0.131 \ddagger$ \\
\hline Etiology & & & & & & & & & & & & $0.645 \dagger$ \\
\hline Ischemic & 11 & 85 & & & & 9 & 69 & & & & & \\
\hline Hemorrhagic & 2 & 15 & & & & 4 & 31 & & & & & \\
\hline \multicolumn{13}{|l|}{ Spasticity (MAS) present } \\
\hline Pectoralis & & & & 0 & $0-3$ & & & & 1 & $0-3$ & 73.500 & $0.543 \ddagger$ \\
\hline Biceps & & & & 1 & $0-3$ & & & & 2 & $0-3$ & 72.000 & $0.505 \ddagger$ \\
\hline \multicolumn{13}{|l|}{ Brunnstrom } \\
\hline Upper extremity & & & & 2 & $1-6$ & & & & 1 & $1-6$ & 71.500 & $0.490 \ddagger$ \\
\hline Hand & & & & 2 & $1-5$ & & & & 2 & $1-6$ & 79.500 & $0.782 \ddagger$ \\
\hline Dominant side & & & & & & & & & & & & 1.000 \\
\hline Right & 13 & 100 & & & & 13 & 100 & & & & & \\
\hline Effected side & & & & & & & & & & & 1.463 & $0.227 \S$ \\
\hline Right & 3 & 23 & & & & 7 & 54 & & & & & \\
\hline Left & 10 & 76 & & & & 6 & 46 & & & & & \\
\hline
\end{tabular}

SD: Standard deviation; Min.: Minimum; Max.: Maximum; ${ }^{\star}$ Student $t$ test; $\dagger$ Fisher’s exact test; $\ddagger$ Mann-Whitney U test; $₫$ Continuity (Yates) Correction Fisher’’ exact test has no test value.

The demographic properties of the patients are shown in Table 1. Group and time showed no statistically significant interaction effect on VAS values and flexion, abduction, internal rotation and external rotation degrees ( $>0.05$ ) (Table 2). There was a significant difference in terms of flexion degrees between the groups $(p<0.05)$. Statistically significant differences were not observed in terms of abduction, internal rotation, external rotation degrees and VAS values between groups $(\mathrm{p}>0.05)$.

There was a statistically significant difference within time in terms of flexion $(\mathrm{p}=0.003)$, abduction $(p=0.003)$ degrees and VAS scores $(p=0.001)$ in group A. There was no significant difference in terms of internal and external rotation degrees within time in group A $(p>0.05)$. There was a statistically significant difference within time in terms of flexion $(\mathrm{p}=0.001)$, abduction $(\mathrm{p}=0.012)$, internal rotation $(p=0.038)$ degrees and VAS scores $(p=0.001)$ in group B, but there was no significant difference in terms of external rotation degrees within time in group $B(p>0.05)$. Time which caused inconsistency in groups has been shown in Table 3 with an asteriks and footnotes.

\section{DISCUSSION}

In this study, it was found that both blinded SSNB and stimulator guided SSNB are effective in reducing pain and improving shoulder ROM angles in patients with HSP. Stimulator guided injections were not found to be superior to blinded SSNB application.

According to our research, this is the first study in the literature comparing the effectiveness of stimulator guided SSNB to that of blinded SSNB application in patients with HSP.

In a review by Fernandes et al. ${ }^{[10]}$ the causes of HSP are mainly subluxation of the shoulder joint and

Table 2. Evaluation of the interaction effects of group and time on parameters

\begin{tabular}{|c|c|c|c|c|c|c|}
\hline & \multicolumn{2}{|c|}{ Time } & \multicolumn{2}{|c|}{ Group } & \multicolumn{2}{|c|}{ Time/group interaction } \\
\hline & $\mathrm{F}$ & $p$ & $\mathrm{~F}$ & $p$ & $\mathrm{~F}$ & $p$ \\
\hline Flexion $\dagger$ & 1.264 & 0.001 & 4.275 & 0.048 & 0.360 & 0.699 \\
\hline Abduction $\dagger$ & 9.604 & 0.001 & 3.812 & 0.063 & 0.749 & 0.478 \\
\hline Internal rotation $\dagger$ & 8.778 & 0.001 & 0.867 & 0.361 & 0.336 & 0.717 \\
\hline External rotation $\dagger$ & 1.783 & 0.179 & 3.953 & 0.058 & 0.310 & 0.735 \\
\hline VAS scores $\ddagger$ & 33.047 & 0.001 & 2.063 & 0.164 & 0.304 & 0.739 \\
\hline
\end{tabular}

$\dagger$ Two Way Mixed ANOVA; $\neq$ F1_LD_F1 Design; VAS: Visual analog scale. 


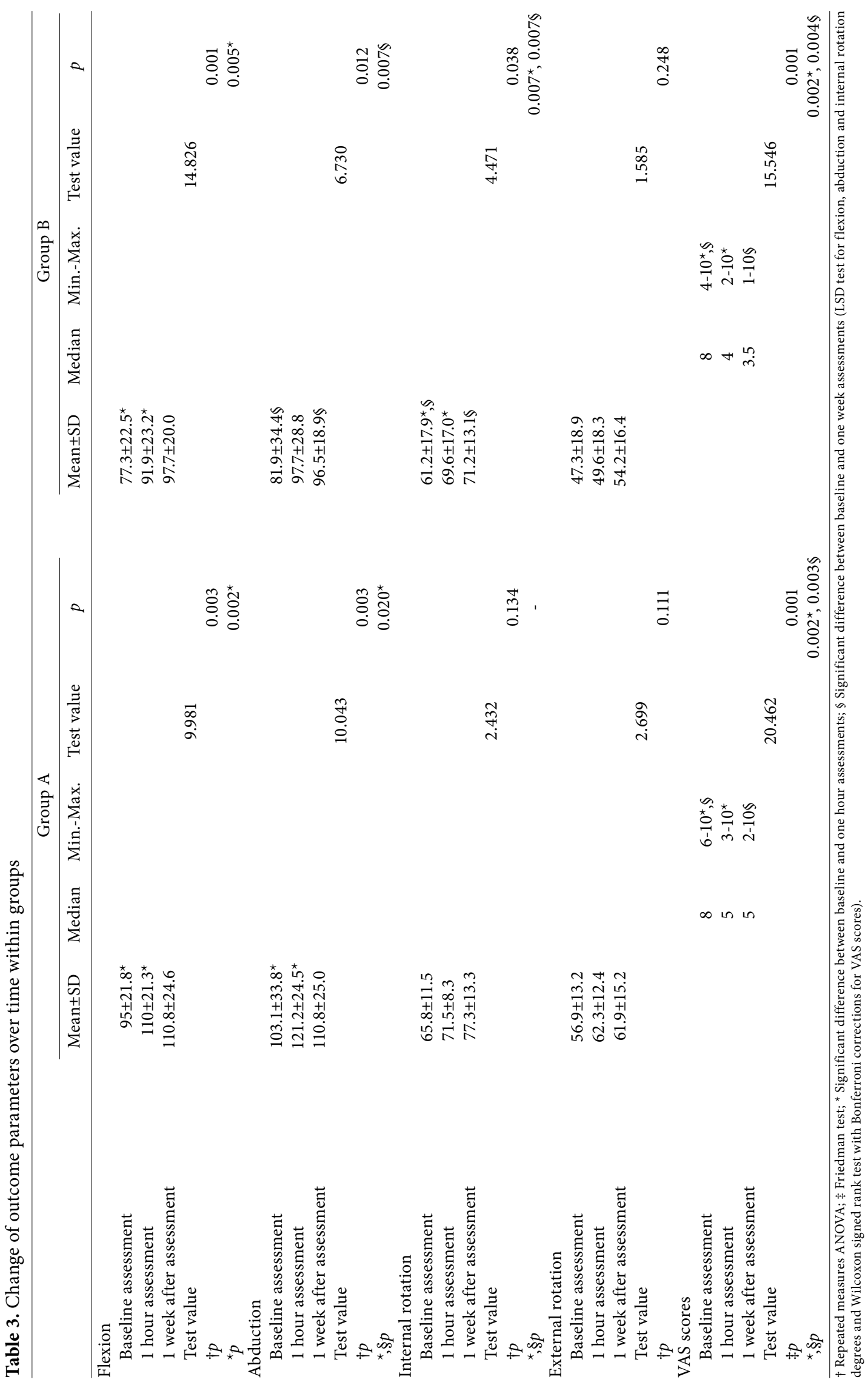


spasticity. Especially, the subscapularis and pectoralis major play a role in increased tonic activity. Thus muscular imbalance and chronic shoulder pain cause poor functional outcome. ${ }^{[10-12]}$ In our study, the majority of patients had spasticity in musculus pectoralis major and musculus biceps brachii.

The main purpose of HSP treatment is to sustain pain relief and to increase ROM angles. For this reason, physical therapy agents, functional electrical stimulation, various injections are used in the rehabilitation stage of hemiplegic patients. ${ }^{[13]}$ Recently, SSNB has become popular in rehabilitation units.

The suprascapular nerve originates from upper trunk of brachial plexus and contains both motor and sensitive branches. The nerve provides motor branches for supraspinatus muscle and infraspinatus muscle, sensitive branches to upper and posterior part of the capsule of the shoulder, acromioclavicular and glenohumeral articulation, coracoclavicular ligament and subacromial bursa. ${ }^{[14,15]}$

Sensitive branches of suprascapular nerve pass below superior transverse scapular ligament. The suprascapular nerve is the largest sensory nerve in the shoulder that supplies $70 \%$ of shoulder innervation; axillary nerve branches supply the rest. It is important to know the anatomic details of the nerve since the success of SSNB is due to accurate needle positioning. ${ }^{[10]}$

The technique for SSNB has been described since 1941, with several definitions and variations throughout the years. ${ }^{[16]}$ Due to decreased pain levels achieved by SSNB, an effective rehabilitation exercise program can be performed. ${ }^{[17]}$ The SSNB has been used for management of acute or chronic pain in shoulder. There are several indications including adhesive capsulitis, shoulder surgery, postoperative pain management, rheumatoid arthritis and hemiplegic shoulder. ${ }^{[10]}$

Emery et al. ${ }^{[18]}$ has shown that SSNB application was superior to intra-articular steroid injection in rheumatoid arthritis patients with chronic shoulder pain. In their study, the blinded application method was used according to the anatomical land markers used for SSNB. Di Lorenzo et al. ${ }^{[19]}$ reported that the addition of SSNB to rehabilitation program has improved the compliance of the patients to physiotherapy, patient's sleep quality and reduced pain level in patients with rotator cuff tendinitis.
In recent literature, there are a few relevant studies about the efficacy of SSNB in HSP. Lee and Khunadorn $^{[20]}$ determined that SSNB was not so efficient in pain relief. On the other hand, Boonsong et al. ${ }^{[21]}$ concluded that SSNB was an effective and safe treatment method for the patients with HSP. In our study, SSNB has been found to be effective in terms of pain level and ROM angles, similar to the results of those studies.

Tubay et al. ${ }^{[22]}$ compared the efficacy of intraarticular steroid injection and SSNB in stroke patients with HSP. They used blinded technique for SSNB and reported that both procedures provided pain relief and improved functional status, with no significant difference.

In a randomized placebo-controlled trial by AdeyWakeling et al., ${ }^{[23]}$ blinded application of SSNB has been reported to be a safe and effective treatment for patients with HSP.

The blinded SSNB technique has been found to be effective in the treatment of HSP in a few studies. However, we speculate that the positioning of the needle at the appropriate area might be difficult in post-stroke patients due to biomechanical changes.

Using guided SSNB techniques, more accurate placement of the tip of the needle in the scapular notch should be obtained rather than blinded application. As such, more successful nerve block and pain control should be possible. ${ }^{[17]}$ In addition; blinded SSNB has more risk such as pneumothorax or damage to suprascapular vessels.

Stimulator, fluoroscopy and ultrasonography (USG) should be used for guidance. Jeon et al. ${ }^{[5]}$ compared the effects of intra-articular steroid injection, SSNB and combined administration of both approaches in patients with HSP. They reported that all the injection regimens, which were performed under USG guidance, had similar beneficial effect in the management of poststroke patients with shoulder pain. There is no study in the literature that applied SSNB in HSP patients with stimulator guidance. In our study, stimulator guided SSNB has not been found to be superior to blinded SSNB in terms of pain relief and improvement of ROM angles.

Fluoroscopy guided nerve block has been widely used for pain management. ${ }^{[24-26]}$ However, if fluoroscopic technique is used frequently, it can cause serious health problems because of exposure to radiation. Fluoroscopy is not preferred to SSNB in rehabilitation practice. 
Ultrasound guided SSNB has been recently reported in the literature with high success rates. ${ }^{[25-27]}$ USG is simple to use and had no irradiation. As such, USG guided SSNB has become more popular among physicians. ${ }^{[28]}$

On the other hand, the stimulation technique for nerve blockage has a high success and low complication rate. ${ }^{[17]}$ The relatively high cost of USG precludes its widespread use when compared to the nerve stimulation technique. In addition, the stimulator is affordable, portable and needs less setup time. ${ }^{[29]}$

Compared to other studies, our follow-up period is very short and should be considered as a limitation for our study. However, our primary aim was to compare two techniques, not long-term efficacy. Further investigations should be designed with larger patient groups and longer follow-up periods.

In conclusion, blinded application of SSNB has been found to be a safe and effective treatment for patients with HSP in this pilot study.

\section{Declaration of conflicting interests}

The authors declared no conflicts of interest with respect to the authorship and/or publication of this article.

\section{Funding}

The authors received no financial support for the research and/or authorship of this article.

\section{REFERENCES}

1. Aras M. Upper extremity problems and their rehabilitation in patients with stroke. J PMR Sci 2006;9(Suppl):14-18

2. McLean DE. Medical complications experienced by a cohort of stroke survivors during inpatient, tertiarylevel stroke rehabilitation. Arch Phys Med Rehabil 2004;85:466-9.

3. Snels IA, Beckerman H, Twisk JW, Dekker JH, Peter De Koning, Koppe PA, et al. Effect of triamcinolone acetonide injections on hemiplegic shoulder pain: A randomized clinical trial. Stroke 2000;31:2396-401.

4. Shanahan EM, Ahern M, Smith M, Wetherall M, Bresnihan B, FitzGerald O. Suprascapular nerve block (using bupivacaine and methylprednisolone acetate) in chronic shoulder pain. Ann Rheum Dis 2003;62:400-6.

5. Jeon WH, Park GW, Jeong HJ, Sim YJ. The Comparison of Effects of Suprascapular Nerve Block, Intra-articular Steroid Injection, and a Combination Therapy on Hemiplegic Shoulder Pain: Pilot Study. Ann Rehabil Med 2014;38:167-73.

6. Walsh K. Management of shoulder pain in patients with stroke. Postgrad Med J 2001;77:645-9.

7. Salgia A, Agarwal T, Puri SR, Sanghi S, Mohapatra A. Role of suprascapular nerve block in chronic shoulder pain: A comparative study of 60 cases. Med J DY Patil Univ 2014;7:44-7.
8. Yasar E, Vural D, Safaz I, Balaban B, Yilmaz B, Goktepe AS, et al. Which treatment approach is better for hemiplegic shoulder pain in stroke patients: intra-articular steroid or suprascapular nerve block? A randomized controlled trial. Clin Rehabil 2011;25:60-8.

9. Moore DC. Block of the suprascapular nerve.. Regional nerve block, 4th ed. Springfield, Illinois: Charles C Thomas 1979. p. 300-3.

10. Fernandes MR, Barbosa MA, Sousa AL, Ramos GC. Suprascapular nerve block: important procedure in clinical practice. Rev Bras Anestesiol 2012;62:96-104.

11. Joynt RL. The source of shoulder pain in hemiplegia. Arch Phys Med Rehabil 1992;73:409-13.

12. Van Ouwenaller C, Laplace PM, Chantraine A. Painful shoulder in hemiplegia. Arch Phys Med Rehabil 1986;67:23-6.

13. Teasell R, Foley N, Bhogal SK, Salter K. Management of post stroke pain [Internet]. London, Canada: Evidence-Based Review of Stroke Rehabilitation; 2012 [cited 2014 Mar 1].

14. Fernandes MR, Fernandes RJ. Indirect arthroscopic decompression of spinoglenoid cyst with suprascapular neuropathy: report of two cases and literature review. Rev Bras Ortop 2015;45:306-11.

15. Checcucci G, Allegra A, Bigazzi P, Gianesello L, Ceruso M, Gritti G. A new technique for regional anesthesia for arthroscopic shoulder surgery based on a suprascapular nerve block and an axillary nerve block: an evaluation of the first results. Arthroscopy 2008;24:689-96.

16. Wertheim HM, Rovenstime FA. Suprascapular nerve block. Anesthesiology 1941;2:541-5.

17. Karataş GK, Meray J. Suprascapular nerve block for pain relief in adhesive capsulitis: comparison of 2 different techniques. Arch Phys Med Rehabil 2002;83:593-7.

18. Emery P, Bowman S, Wedderburn L, Grahame R. Suprascapular nerve block for chronic shoulder pain in rheumatoid arthritis. BMJ 1989;299:1079-80.

19. Di Lorenzo L, Pappagallo M, Gimigliano R, Palmieri E, Saviano E, Bello A, et al. Pain relief in early rehabilitation of rotator cuff tendinitis: any role for indirect suprascapular nerve block? Eura Medicophys 2006;42:195-204.

20. Lee KH, Khunadorn F. Painful shoulder in hemiplegic patients: a study of the suprascapular nerve. Arch Phys Med Rehabil 1986;67:818-20.

21. Boonsong $\mathrm{P}$, Jaroenarpornwatana A, Boonhong J. Preliminary study of suprascapular nerve block (SSNB) in hemiplegic shoulder pain. J Med Assoc Thai 2009;92:1669-74.

22. Tubay A, Bal S, Bayram KB, Koçyiğit H, Gürgan A. Suprascapular nerve block and glenohumeral injection in hemiplegic shoulder pain: to compare the effectiveness on pain and disability. Turk J Phys Med Rehab 2012;58:299-303.

23. Adey-Wakeling Z, Crotty M, Shanahan EM. Suprascapular nerve block for shoulder pain in the first year after stroke: a randomized controlled trial. Stroke 2013;44:3136-41.

24. Peng PW, Wiley MJ, Liang J, Bellingham GA. Ultrasoundguided suprascapular nerve block: a correlation with fluoroscopic and cadaveric findings. Can J Anaesth 2010;57:143-8. 
25. Siegenthaler A, Moriggl B, Mlekusch S, Schliessbach J, Haug $\mathrm{M}$, Curatolo $\mathrm{M}$, et al. Ultrasound-guided suprascapular nerve block, description of a novel supraclavicular approach. Reg Anesth Pain Med 2012;37:325-8.

26. Harmon D, Hearty C. Ultrasound-guided suprascapular nerve block technique. Pain Physician 2007;10:743-6.

27. Chan CW, Peng PW. Suprascapular nerve block: a narrative review. Reg Anesth Pain Med 2011;36:358-73.

28. Shim JH. Is Fluoroscopy-guided Suprascapular Nerve Block Better Than Other Techniques? Korean J Pain 2013;26:102-3.

29. Bowens C Jr, Sripada R. Regional blockade of the shoulder: approaches and outcomes. Anesthesiol Res Pract 2012;2012:971963. 